\title{
Alignment of Knowledge Management and Performance Management System (Case Study: PT. X)
}

\author{
Atikah Aghdhi Pratiwi \\ Department of Industrial Engineering, Institut Teknologi Sepuluh Nopember Surabaya \\ atikah.aghdhi@gmail.com
}

\begin{abstract}
Purpose: Improve company's performance by capturing critical knowledges of employee in each Department.

Design/methodology/approach: Knowledge audit is used to capture the knowledge database, and Analytical Hierarchy Process (AHP) is used to obtain critical knowledge.

Findings: The results show that there are 30 points knowledges with 3 critical knowledges in the Department of Production.

Research limitations/implications: The study focused only on E-Print product, especially for Department of Production.

Practical implications: Knowledge is one of intangible assets in a company. Aligning knowledge with performance management system will support the company to achieve it's goaals and the sustainability of the company.
\end{abstract}

Paper type: This paper can be categorized as case study paper.

Keyword: Alignment, Analytical Hierarchy Process (AHP), Knowledge, Knowledge Audit, Knowledge Management, Performance Management.

$\begin{array}{lll}\text { Received } & : & \text { June } 10^{\text {th }} 2019 \\ \text { Revised } & : & \text { July } 17^{\text {th }} 2019 \\ \text { Published } & : & \text { September } 30^{\text {th }} 2019\end{array}$

\section{INTRODUCTION}

The increase of competition in this globalization era pushes companies to make innovations and improvements to their business processes and performance. One of the important factors that affect performance in a company is knowledge. Davenport and Pruzak (1998) define knowledge as a mixture of experience, contextual value, information and views of the fundamental experts and intuitions that provide a framework for evaluating and integrating new experiences with information. In a company, knowledge is not only related to documents and storage of valuables, but also the routines of an organization, processes, norms, and practices within the enterprise. To make knowledge more valuable and useful for the company, knowledge must be well managed (Nonaka \& Takeuchi, 1995). According to Roy et al (2000), knowledge management is one of the important and powerful tools for companies to manage their resources, to achieve the expected competitive advantage.

Murray (2002) said, basically knowledge management is the act of managing corporate knowledge and intelligence assets that can improve performance on an organization scale and provide added value. Brooking (1997) defined it as an activity related to strategy and tactics to manage assets 
in the form of human resources. If concluded, knowledge management is an activity to manage process and knowledge resources in order to improve competitive advantage and performance of an organization (Wong \& Aspinwall, 2006). Performance measurement is an important and crucial thing in knowledge management, because performance measurement is a foundation that enables an organization to evaluate, control and improve its knowledge processes (Pervaiz, et al, 1999, Wong, 2005). So it can be concluded that performance measurement and knowledge management are two things that have relevance, and by building a knowledge management system that is aligned with performance measurement system, a company will be able to evaluate and control its owned intelligence assets better, and improve its performance to be able to achieving the expected competitive advantage. In addition, by implementing a knowledge management system that aligns with performance measurement, the company will be able to minimize and overcome the gaps that occur between processes of knowledge on business processes and performance indicators related to business objectives (Roy \& et al, 2000). With the knowledge management system, it is expected that the company can also protect its intelligence assets from human resource problems such as retirement (retirement), hijack (piracy), and turnover (work move).

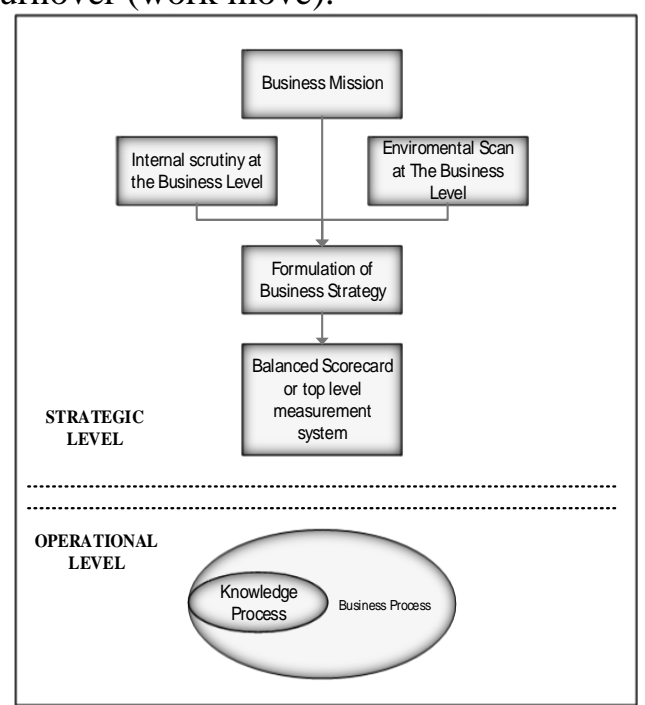

Fig 1. The Gap between Business Process and Knowledge Process (Roy \& et al, 2000)

Figure 1 shows the gap in the entire organization map. Gap is exist caused by companies that have previously had a complete performance measurement system and knowledge recognition process. The contribution of the knowledge process can be measured by the lag indicators affecting the process, but there is a lack of solution in knowledge management lead indicator. The other hand, the lag indicators measure business performance that supports the achievement of strategic objectives, and on another side, there is a new knowledge process that accomplishes the knowledge bottleneck on the business process. When associated with performance measurement, knowledge management serves to boost the company's intellectual assets to achieve company goals, and improve company performance in terms of equitable distribution of information, and show how the performance of a business process within a company. PT. X should improve its performance as the increase of product demand and competition. To be able to know the fluctuation of company performance, hence must first be done evaluation or performance appraisal of company done periodically.

This study will formulate knowledge database and support the achievement of strategic objectives of the company, weighting the knowledge points so that it is known critical knowledge for the company, and set up performance indicators for each knowledge point align with the existing performance indicator. PT. X is a IT solution specialist company, especially in gas station IT needs. The formulated knowledge database focused on one of the best seller product, which called E-Print and its IT system related to reporting daily operational aspects. Based on the outputs, the company 
can measure the performance of internal stakeholders of the company in terms of equitable information / knowledge related to the performance of the company.

\section{METHODOLOGY}

This research will be conducted into several steps:

\section{A. Problem Statement Formulation and Goal Setting}

In this step, brainstorming with The CEO of PT. X will be conducted, because CEO is considered to be the one who most understand about the knowledge management and performance measurement system in existing condition. Problem Identification obtained from information gathering. After the problems and its sources determined, the next step is formulation the problem statement to be solved through this research and the the purpose of research determined as well.

\section{B. Data Collection}

Data collected is about company's condition and identify the required knowledge. The following data must be collected to be able to analyze the Company's condition.

- Identify Existing Knowledge Management and Performance Measurement Existing

At this stage, the existing performance measurement system of the company is identified. In the current condition, PT. X use Balanced Scorecard as performance measurement system. But, PT. X does not have a knowledge database.

- $\quad$ Knowledge Audit

At this stage, data collection is conducted (knowledge audit). Data needed are about knowledge needed in providing E-Print Products. Knowledge audit only focused on Department of Production. The methods used for knowledge audit are questionnaires and interviews. Interviews and questionnaires distributed to experts in Department of Production. Knowledge points obtained used as data processing materials.

\section{Data Processing}

Here are the steps performed on data processing.

- Knowledge Database and Properties

In this section, a knowledge database developed according to the existing strategic objective of the Department of Production. The development use data obtained from the knowledge audit. The creation of Knowledge Properties from each knowledge points obtained from the previous step. The purpose of knowledge properties creation is to prevent the ambiguity perception of that knowledge points.

\section{- Identify The Weight of Each Knowledge}

In this section, each knowledge points weighted by using AHP, so it can be known which knowledge has the biggest weight or critical effect to achieve the strategic objectives of the Department of Production.

\section{Data Analysis and Interpretation}


The results of data processing that has been obtained will be analyzed, based on strategic objectives associated with the Department of Prodduction, analysis of weighting knowledge, and the weight value assigned to each knowledge point.

\section{RESULTS AND DISCUSSION}

Based on the observation process, it was known that PT. X use Balanced Scorecard (BSC) as performance measurement system. Knowledge audit conducted to determine knowledges that give contribution to each KPI of Department of Production. The methods used for knowledge audit are questionnaires and interviews. Interviews and questionnaires distributed to experts in each Department. As the result, in Production Department there are 4 KPIs supported by 30 knowledge points. Knowledge is related to each strategy goal that must be achieved, so those must be owned by each employee in the Department of Production.

\section{A. Knowledge Database}

Table 1 shows the knowledge database for Production Department.

Table 1. Knowledge Database of Production Department

\begin{tabular}{|c|c|c|c|c|c|c|}
\hline $\begin{array}{l}\text { Perspectiv } \\
\text { e }\end{array}$ & $\begin{array}{c}\text { Cod } \\
\text { e }\end{array}$ & $\begin{array}{l}\text { Strategic } \\
\text { Objective }\end{array}$ & KPI & $\begin{array}{l}\text { Knowledg } \\
\text { e Index }\end{array}$ & Knowledge & $\begin{array}{l}\text { Knowledge } \\
\text { Properties }\end{array}$ \\
\hline \multirow{3}{*}{ Finance } & \multirow{3}{*}{ F01 } & \multirow{3}{*}{$\begin{array}{c}\text { Efficient } \\
\text { Cost } \\
\text { Managemen } \\
\mathrm{t}\end{array}$} & \multirow{3}{*}{$\begin{array}{c}\text { a. } \\
\text { Production } \\
\text { Cost } \\
\text { effiency }\end{array}$} & PKF1 & Cost Management & $\begin{array}{l}\text { Conduct } \\
\text { maintenance } \\
\text { activities of } \\
\text { production } \\
\text { facilities } \\
\text { according to } \\
\text { RKAPi } \\
\text { dengan } \\
\text { RKAP }\end{array}$ \\
\hline & & & & PKF2 & $\begin{array}{l}\text { Budget Management } \\
\text { \& Financial Planning }\end{array}$ & $\begin{array}{l}\text { Plan the } \\
\text { maintenance } \\
\text { activities of } \\
\text { the facility } \\
\text { by paying } \\
\text { attention to } \\
\text { the budget } \\
\text { allocation } \\
\text { provided and } \\
\text { has been } \\
\text { listed in the } \\
\text { RKAP }\end{array}$ \\
\hline & & & & PKF3 & $\begin{array}{l}\text { Financial Statement } \\
\text { Analysis }\end{array}$ & $\begin{array}{l}\text { Read the } \\
\text { Department's } \\
\text { financial } \\
\text { statements } \\
\text { and analyze } \\
\text { unnecessary } \\
\text { and } \\
\text { inefficient }\end{array}$ \\
\hline
\end{tabular}

Alignment of Knowledge Management and Performance Measurement System (Case Study: PT.X) 


\begin{tabular}{|c|c|c|c|c|c|c|}
\hline \multirow[t]{2}{*}{$\begin{array}{l}\text { Perspectiv } \\
\text { e }\end{array}$} & \multirow[t]{2}{*}{$\begin{array}{c}\text { Cod } \\
\text { e }\end{array}$} & \multirow[t]{2}{*}{$\begin{array}{l}\text { Strategic } \\
\text { Objective }\end{array}$} & \multirow[t]{2}{*}{ KPI } & $\begin{array}{l}\text { Knowledg } \\
\text { e Index }\end{array}$ & \multirow[t]{2}{*}{ Knowledge } & \multirow{2}{*}{$\begin{array}{l}\begin{array}{l}\text { Knowledge } \\
\text { Properties }\end{array} \\
\text { sources of } \\
\text { expenditure }\end{array}$} \\
\hline & & & & & & \\
\hline \multirow{22}{*}{$\begin{array}{l}\text { Internal } \\
\text { Business } \\
\text { Process }\end{array}$} & \multirow{20}{*}{ I01 } & \multirow{20}{*}{$\begin{array}{c}\text { Product } \\
\text { quality } \\
\text { assurance } \\
\text { Improveme } \\
\text { nt }\end{array}$} & \multirow{20}{*}{$\begin{array}{c}\text { a.\% } \\
\text { Quality } \\
\text { Assurance } \\
\text { Factor } \\
\text { (QAF) }\end{array}$} & PKKP1 & $\begin{array}{l}\text { Electrical component } \\
\text { function }\end{array}$ & \multirow{20}{*}{$\begin{array}{l}\text { Understandin } \\
\mathrm{g} \text { the flow of } \\
\text { the use of } \\
\text { hard and soft } \\
\text { components } \\
\text { of E-print } \\
\text { products } \\
\text { well, so that } \\
\text { the product } \\
\text { always has } \\
\text { quality } \\
\text { assured and } \\
\text { able to } \\
\text { satisfy } \\
\text { consumers }\end{array}$} \\
\hline & & & & PKKP2 & $\begin{array}{l}\text { Electrical component } \\
\text { system workflow }\end{array}$ & \\
\hline & & & & PKKP3 & Main pannel function & \\
\hline & & & & PKKP4 & Soldering technique & \\
\hline & & & & PKKP5 & Coloring & \\
\hline & & & & PKKP6 & $\begin{array}{l}\text { Main pannel } \\
\text { assembling }\end{array}$ & \\
\hline & & & & PKKP7 & Pannel layout setting & \\
\hline & & & & PKKP8 & Software Installation & \\
\hline & & & & PKKP9 & $\begin{array}{l}\text { Algorithm structure } \\
\text { framework }\end{array}$ & \\
\hline & & & & PKKP10 & Coding & \\
\hline & & & & PKKP11 & $\begin{array}{l}\text { Logical structure } \\
\text { software building }\end{array}$ & \\
\hline & & & & PKKP12 & $\begin{array}{l}\text { Software features } \\
\text { planning }\end{array}$ & \\
\hline & & & & PKKP13 & $\begin{array}{l}\text { User interface } \\
\text { development }\end{array}$ & \\
\hline & & & & PKKP14 & $\begin{array}{l}\text { Bug source } \\
\text { recognition }\end{array}$ & \\
\hline & & & & PKKP15 & Sampling testing & \\
\hline & & & & PKKP16 & Data report analysis & \\
\hline & & & & PKKP17 & $\begin{array}{l}\text { Development/reparati } \\
\text { on planning }\end{array}$ & \\
\hline & & & & PKKP18 & $\begin{array}{l}\text { Product workflow } \\
\text { system }\end{array}$ & \\
\hline & & & & PKKP19 & Critical electrical part & \\
\hline & & & & PKKP20 & $\begin{array}{l}\text { Server \& cloud } \\
\text { computing }\end{array}$ & \\
\hline & \multirow[t]{2}{*}{ I02 } & \multirow[t]{2}{*}{$\begin{array}{c}\text { HSE } \\
\text { Improveme } \\
\mathrm{nt}\end{array}$} & \multirow[t]{2}{*}{$\begin{array}{c}\text { b. } \\
\text { Accident } \\
\text { Rate }\end{array}$} & PKKP21 & Safety compliance & $\begin{array}{l}\text { Generalize } \\
\text { employee } \\
\text { knowledge } \\
\text { about safety } \\
\text { standards in } \\
\text { conducting } \\
\text { production } \\
\text { operations } \\
\text { and use PPE }\end{array}$ \\
\hline & & & & PKKP22 & Risk management & $\begin{array}{l}\text { Generalize } \\
\text { employee } \\
\text { knowledge } \\
\text { about }\end{array}$ \\
\hline
\end{tabular}

Alignment of Knowledge Management and Performance Measurement System (Case Study: PT.X) 


\begin{tabular}{|c|c|c|c|c|c|c|}
\hline \multirow[t]{2}{*}{$\begin{array}{l}\text { Perspectiv } \\
\text { e }\end{array}$} & \multirow[t]{2}{*}{$\begin{array}{c}\text { Cod } \\
\text { e }\end{array}$} & \multirow[t]{2}{*}{$\begin{array}{l}\text { Strategic } \\
\text { Objective }\end{array}$} & \multirow[t]{2}{*}{ KPI } & $\begin{array}{c}\text { Knowledg } \\
\text { e Index }\end{array}$ & Knowledge & $\begin{array}{l}\text { Knowledge } \\
\text { Properties }\end{array}$ \\
\hline & & & & & & $\begin{array}{l}\text { production } \\
\text { risk } \\
\text { management, } \\
\text { so as to } \\
\text { reduce } \\
\text { accident or } \\
\text { work } \\
\text { accident }\end{array}$ \\
\hline \multirow{5}{*}{$\begin{array}{l}\text { Learning } \\
\text { \& Growth }\end{array}$} & \multirow{5}{*}{ L01 } & \multirow{5}{*}{$\begin{array}{c}\text { Potential } \\
\text { employees } \\
\text { developmen } \\
\text { t }\end{array}$} & \multirow{5}{*}{$\begin{array}{c}\% \\
\text { Average } \\
\text { of } \\
\text { competenc } \\
\text { y standard } \\
\text { fulfillment }\end{array}$} & PKP1 & Training management & $\begin{array}{l}\text { Adjust the } \\
\text { number of } \\
\text { hours of } \\
\text { training } \\
\text { according to } \\
\text { the needs of } \\
\text { employees }\end{array}$ \\
\hline & & & & PKP2 & $\begin{array}{l}\text { Performance } \\
\text { Appraisal } \\
\text { management }\end{array}$ & $\begin{array}{l}\text { Perform } \\
\text { regular and } \\
\text { structured } \\
\text { assessment }\end{array}$ \\
\hline & & & & \multirow{3}{*}{ PKP3 } & Leadership & $\begin{array}{l}\text { Able to lead } \\
\text { and follow } \\
\text { the } \\
\text { leadership in } \\
\text { a team so as } \\
\text { to create } \\
\text { good } \\
\text { cooperation }\end{array}$ \\
\hline & & & & & Innovative thinking & $\begin{array}{l}\text { Having } \\
\text { innovative } \\
\text { thinking } \\
\text { related to E- } \\
\text { print } \\
\text { operational } \\
\text { and } \\
\text { production } \\
\text { activities }\end{array}$ \\
\hline & & & & & Integrative thinking & $\begin{array}{l}\text { Having } \\
\text { integrative } \\
\text { thinking and } \\
\text { can analyze } \\
\text { problems } \\
\text { from all } \\
\text { sides }\end{array}$ \\
\hline
\end{tabular}

From Table 1 it is known that Production Department has 4 strategic objectives (SO) that supported by 4 KPIs. Each KPI has supporting knowledges. As an example, SO: Efficient cost management supported by KPI: Production cost efficiency. KPI: Production cost efficiency supported by 3 knowledges, those are cost management (PKF1), budget management \& financial planning (PKF2), 
and financial statement analysis (PKF3). Based on the result, in can be concluded that if Production Department wants to achieves the target of efficient cost management, all of the employees in Production Department must have all of the knowledge above.

\section{B. Overall Weight Value Formula}

Each knowledge point in Production Department was weighted to find the critical and important knowledge. Weighting process conducted by Analytical Hierarchy Process (AHP). A weighted questionnaire was given to Department Manager and CEO of PT. X.

Figure 2 shows the result of weighting process of each knowledges in Production Department.

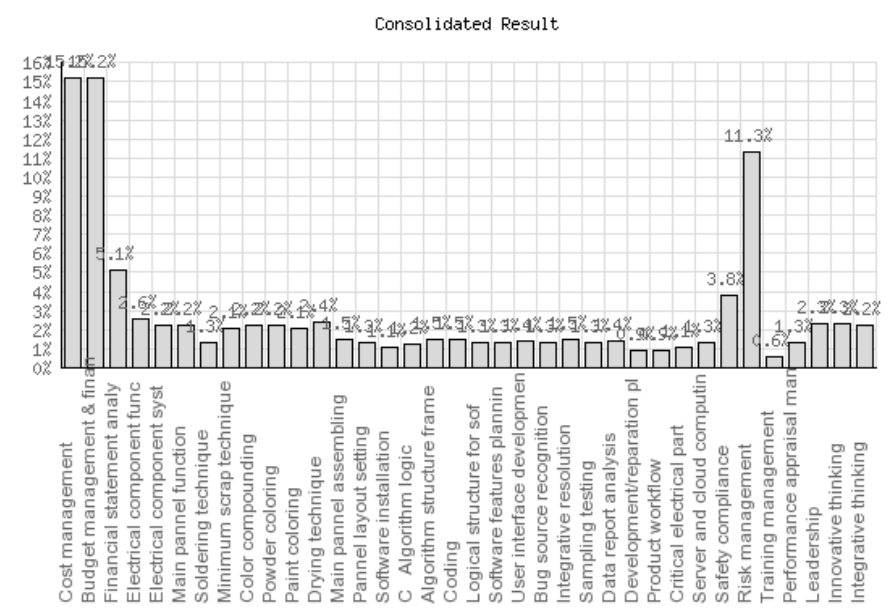

Fig 2. Consolidated Global Priorities of Knowledges in Production Department

Based on figure 2 above, it is known that in Production Department, there are three knowledge points that have significantly higher weight compared to other knowledge points, they are Cost Management (15.2\%), Budget Management \& financial planning (15.2\%), and Risk Management (11.3\%). In the detail knowledge of KPI\% Quality assurance factor, the knowledge is more technical, and become core knowledge that must be owned by employees in Production Department, so that the average weight of knowledge in KPI tends to be smaller because the weight value is more evenly distributed. In addition to technical knowledge, employees must also have managerial knowledge, especially in the areas of finance and operational risk management. Because the status of PT. X as a medium-sized company still has to focus on financial stability and health. In addition, knowledge risk management emerges as critical knowledge because PT. X wants that every employee be aware of the risks, both physical risks on the production floor, to the risks of the resulting product that will affect financial performance.

\section{CONCLUSION}

Knowledge database for Production Department in PT. X has been formulated. It is known that in Department of Production, Threre are 4 KPIs that supported by 30 knowledge points. There are 3 critical knowledges points compared to other knowledge points: Cost Management (15.2\%), Budget Management \& financial planning (15.2\%), and Risk Management (11.3\%). It means, in order to achieve its strategic objectives, all of the employees in Production Department must have all the Alignment of Knowledge Management and Performance Measurement System (Case Study: PT.X) 
knowledges previously mentioned. Based on the result of the study, it can be concluded that knowledge is one of important part to achieve company's goals.

\section{REFERENCES}

Brooking, A., (1997). The Management of intellectual capital. Long Range Plan, pp. 30 (3) : 364-365.

Chen, A. \& Chen, M., (2005) : 1995 - 2004. A review of survey research in Knowledge Management performance measurement. Journal of Universal Knowledge Management, pp. 1: 4-12..

De Jarnett, L., (1996). Knowledge the Latest Thing. Information Strategy : Executive Journal, pp. 12(2): $3-5$..

Kaplan, R. \& Norton, D., (2000). Balanced Scorecard, Menerapkan Strategi Menjadi Aksi. Jakarta: Erlangga.

Luis, S., (2007). Step by Step in Cascading Balanced Scorecard to Functional Scorecards. Jakarta: Gramedia Pustaka Utama.

Murray, P., (2002). Knowledge Management as a sustained competitive advantage. pp. 66(4): 71-76.

Nonaka, I. \& Takeuchi, H., (1995). How Japanese Companies Create The Dynamics in Innovation. The Knowledge Creating Company :

Paramasivan, T., (2003). Knowledge Audit, India: The Institute of Chartered Accountants of India.

Parmenter, D., (2007). Key Performance Indicators : Pengembangan, Implementasi, dan Penggunaan KPI Terpilih. 1 penyunt. Jakarta: PT. Elex Media Komputindo.

Roy et al, R., (2000). A Framework to Create Performance Indicators in Knowledge Management. Proc. of The Third Intl. Conf. on Practical Aspects of Knowledge Management (PAKM2000), pp. 1-8.

Roy, R. \& et al, (2000). A Framework to Create Performance Indicators in Knowledge Management. Proc. of The Third Intl. Conf. on Practical Aspects of Knowledge Management (PAKM2000), pp. 1-8.

Saaty, T. L., (1990). The Analytical Network Process.

Sholihah, M., (2013). Perancangan Sistem Pengukuran Kinerja ITS International Office Dengan Menggunakan Balanced Scorecard (Laporan Tugas Akhir), Surabaya: ITS, Jurusan Teknik Industri.

Sipayung , F., (2009). Balanced Scorecard : Pengukuran Kinerja Perusahaan dan Sistem Manajemen Strategis. Jurnal Manajemen Bisnis, pp. 7-14.

Suwignjo, P., (2009). Manajemen Performansi [Power Point Slides], Surabaya: Teknik Industri ITS.

Wong, K. \& Aspinwall, E., (2006). Development of a Knowledge Management initiative and system: a case study.,.. Expert System Application, pp. 30(4): 633-641.

Wu, W.-W., (2008). Choosing Knowledge Management strategies by using a combined ANP and DEMATEL approach. Expert Systems with Applications, 12(1), pp. 828-835. 
Wu, W.-W., (2012). Segmenting critical factors for successful knolwedge Management implementation using the fuzzy DEMATEL method. Applied Soft Computing, 12(1), pp. 527-535.

Yuliazmi, (2011). Penerapan Knowledge Management pada Perusahaan Reasuransi : Studi Kasus PT. Reasuransi Nasional Indonesia, Jakarta: Magister Ilmu Komputer - Universitas Budi Luhur. 